\title{
ANALISIS PENERAPAN PP 23 TAHUN 2018 PADA WAJIB PAJAK UMKM (STUDI DI KANTOR PELAYANAN PAJAK PRATAMA MAKASSAR UTARA)
}

\author{
Memi Pratiwi. AM \\ Universitas Muslim Indonesia \\ Email: memipratiwi@gmail.com \\ Fadliah Nasaruddin \\ Universitas Muslim Indonesia \\ Email: fadliah.nas@gmail.com \\ Syamsu Alam \\ Universitas Muslim Indonesia \\ Email: Syamsul.alam@ish.co.id
}

\begin{abstract}
Abstrak
Penelitian ini bertujuan untuk menganalisis dan mengetahui penerapan PP 23 Tahun 2018 pada Wajib Pajak UMKM di Kantor Pelayanan Pajak Pratama Makassar Utara. Data yang digunakan dalam penelitian ini adalah data primer dan data sekunder. Metode pengumpulan data menggunakan wawancara dan dokumentasi. Teknik analisis data menggunakan analisis kualitatif. Hasil penelitian menunjukkan bahwa penerapan PP 23 Tahun 2018 pada Wajib Pajak UMKM di Kantor Pelayanan Pajak Pratama Makassar Utara sudah berjalan dengan baik dan sesuai dengan prinsip - prinsip pemungutan pajak. Besaran tarif pajak yang diturunkan menjadi 0,5\%, administrasi perpajakan yang murah dan prosedur penyetoran yang mudah merupakan gambaran impelementasi prinsip pemungutan equality, certainty, convenience, dan economy.
\end{abstract}

Kata kunci: PP No. 23 Tahun 2018, Wajib Pajak dan UMKM

\section{Abstract}

The purpose of this re search is to analze identify application PP No. 23 Year 2018 on Taxpayer MSMEs on Tax Service Office Pratama North Makassar.The data required in this study is primary data and secondary data. Data collection methods used in this study is the interview and documentary. Data analysis techniques used by kualitative analysis. The results showed that the implementation of PP No. 23 Year 2018 on Taxpayer MSMEs on Tax Service Office Pratama North Makassar has been going well and is in accordance with the principles of tax collection. The lowered tax rate to 0.5\%, cheap tax administration and easy deposit procedures illustrate the implementation of the principles of equality, certainty, convenience and economy.

Keyword: PP No. 23 Year 2018, Taxpayer, MSMEs 


\section{PENDAHULUAN}

Sektor Usaha Mikro Kecil Menengah (UMKM) sudah beberapa tahun belakangan ini menjadi pusat perhatian dikarenakan telah menjelma menjadi sumber penggerak ekonomi baru di Indonesia. Tidak tanggung- tanggung kontribusi yang diberikan UMKM terhadap Produk Domestik Bruto (PDB) tercatat mencapai 61,41 persen. Dengan tingkat kontribusi tersebut, UMKM setidaknya menyerap hampir 97 persen total tenaga kerja nasional dan memiliki proporsi 99 persen dari total pelaku usaha di Indonesia.

Hal ini yang mendasari Pemerintah untuk berencana menjadikan UMKM sebagai fokus atau target pemajakan yang telah terdengar sejak pertengahan tahun 2011 (economy.okezone.com, 2013).Saat itu sumber data menunjukkan bahwa UMKM menyumbang 61 persen dari Produk Domestik Bruto tetapi kontribusinya terhadap total penerimaan pajak hanya 5 persen sungguh ironi memang persentase pemasukan tidak sampai $10 \%$.

Pemerintah terus berupaya meningkatkan pendapatan dari sector UMKM dengan mengeluarkan Peraturan NO 46 Tahun 2018 sebagai suatu kebijakan sebesar $1 \%$ mengenai aturan perpajakan dikalangan UMKM (www.minghadi.com, 2013). Peraturan perpajakan yang baru ini diklaim mempermudah pembayaran pajak oleh wajib pajak di Indonesia, terutama target utama dari Peraturan Pemerintah ini adalah kalangan UKM (Usaha Kecil Menengah) dikutip dari (www.minghadi.com, 2013). Namun pada Praktiknya ternyata win-win solution yang ditawarkan oleh pemerintah ini belum cukup efektif untuk meningkatkan pemasukan negara pada sector Pajak.
Pada tahun 2017, Badan Kebijakan Fiskal (BKF) Kementerian Keuangan mengungkapkan, kajian perubahan penghitungan tarif Pajak Penghasilan $(\mathrm{PPh})$ berupa tarif pajak final atau tidak, masih terus dibahas bersama dengan Direktorat Jenderal Pajak (DJP) terutama mengenai implementasi PP. Nomor 46 Tahun 2013 ini (CNN Indonesia.com, 2017) dan (Majalah UKM, 2014). Oleh karena itu, terjadinya banyak polemik ditengah-tengah pelaku usaha maka Menteri Keuangan Sri Mulyani mengajukan revisi ulang terkait PP. No. 46 Tahun 2013 tersebut. Peninjauan kembali mengenai Peraturan Pemerintah tersebut dengan menurunkan jumlah setoran pajak yang semula $1 \%$ menjadi 0.5\% (www.metrotvnews.com, 2018). Hal ini bertujuan agar tentunya tidak memberatkan para pelaku usaha dan menciptakan win-win solution dan asas "Fairness" bagi pemerintah dan juga bagi pelaku usaha itu sendiri.

Kebijakan ini diharapkan para pelaku UMKM yang selama ini belum memberikan kontribusi kepada negara melalui pajak segera sadar dan taat pajak. Bukti masih rendahnya kepatuhan Wajib Pajak ditunjukkan dengan realisasi penyampaian Surat Pemberitahuan Tahunan (SPT) 2018 di Kantor Perwakilan (Kanwil) Direktorat Jenderal Pajak (DJP) Sulselbartra khusus di Kota Makassar masih cukup rendah, yakni baru mencapai 28,40 persen (www.rakyatku.com).

Rendahnya pemenuhan kewajiban perpajakan bagi wajib pajak menunjukkan rendahnya kepatuhan wajib pajak, sehingga menyebabkan belum optimalnya penerimaan pajak di Indonesia.Khususnya penerimaan pajak dari UMKM. 
Berikut ini dapat dilihat perbandingan data UMKM di Kota Makassar dan data wajib pajak orang pribadi UMKM yang terdaftar di KPP Pratama Makassar Utara dari tahun 2017 - 2019.

Tabel 1

Perbandingan Data UMKM di Kota Makassar dan Data Wajib Pajak Orang Pribadi PP No. 23 di KPP Prima Makassar Utara

Tahun 2017 - 2019

\begin{tabular}{|c|c|c|c|c|}
\hline $\mathrm{N}$ & Tahun & $\begin{array}{c}\text { Jumlah } \\
\text { Usaha } \\
\text { Mikro, } \\
\text { Kecil } \\
\text { dan } \\
\end{array}$ & $\begin{array}{c}\text { Jumlah } \\
\text { Wajib } \\
\text { Pajak } \\
\text { PP No. } \\
46 / 20 \\
\text { Meneng } \\
\text { ah }\end{array}$ & $\begin{array}{c}\text { Perse } \\
\text { ntase }\end{array}$ \\
\hline 1. & 2017 & 16.226 & 3.830 & $\begin{array}{c}23,60 \\
\%\end{array}$ \\
\hline 2. & 2018 & 17.264 & 5.056 & $\begin{array}{c}29,29 \\
\%\end{array}$ \\
\hline 3. & 2019 & 18.302 & 5.654 & $\begin{array}{c}30,89 \\
\%\end{array}$ \\
\hline
\end{tabular}

Sumber: Seksi pengolahan Data dan Informasi Dinas Koperasi dan UMKM kota Makassar dan KPP Pratama Makassar Utara.

Berdasarkan Tabel 1 di atas maka dapat dilihat bahwa dari tahun 2017 hingga tahun 2019, jumlah UMKM yang ada di Kota Makassar yang terdaftar di KPP Prima Makassar Utara mengalami peningkatan dari 23,60 menjadi 30,89\%. Masih kurangnya jumlah UMKM yang terdaftar di KPP Prima Makassar Utara menjadi suatu fenomena yang perlu untuk ditelusuri penyebabnya.

\section{TINJAUAN PUSTAKA}

\subsection{Teori Pemajakan}

Menurut Adam Smith (1776) dalam Poluan (2010), ada empat prinsip yang harus dipegang teguh dalam pemungutan pajak:
1. Equality, yaitu pajak harus adil dan merata, dikenakan kepada orangorang pribadi sebanding dengan kemampuannya untuk membayar pajak tersebut, dan sesuai dengan manfaat yang diterimanya.

2. Certainty, yaitu pajak tidak ditentukan secara sewenang-wenang, sebaliknya pajak itu harus dari semula jelas bagi semua Wajib Pajak dan seluruh masyarakat

3. Convenience, yaitu saat Wajib Pajak harus membayar pajak hendaknya ditentukan pada saat yang tidak akan menyulitkan Wajib Pajak.

4. Economy, yaitu biaya pemungutan bagi kantor pajak dan biaya memenuhi kewajiban pajak oleh Wajib Pajak hendaknya sekecil mungkin.

\subsection{Pajak}

\section{a. Pengertian Pajak}

Definisi pajak yang dikemukakan oleh (Waluyo, 2014) adalah iuran rakyat kepada negara berdasarkan undangundang (yang dapat dipaksakan) dengan tidak mendapat jasa timbal balik (kontraprestasi) yang langsung dapat ditujukkan, dan yang digunakan untuk membayar pengeluaran umum.Dari definisi tersebut dapat disimpulkan bahwa pajak memiliki unsur-unsur:

1) Iuran rakyat kepada negara Yang berhak memungut pajak adalah negara, iuran tersebut adalah uang bukan barang.

2) Berdasarkan undang - undang Pajak dipungut berdasarkan atau dengan kekuatan undang-undang serta aturan pelaksanaannya

3) Tanpa jasa timbal balik atau kontraprestasi dari negara yang secara langsung dapat ditunjuk. Dalam pembayaran pajak tidak dapat 
ditunjukan adanya kontrprestasi individual oleh pemerintah

4) Digunakan untuk membiayai rumah tangga negara, yakni pengeluaranpengeluaran yang bermanfaat bagi masyarakat luas.

\section{b. Fungsi Pajak}

Menurut (Yenni Mangoting, 2000)Terdapat dua fungsi pajak, yaitu fungsi budgetair (sumber keuangan negara) dan fungsi regulated (mengatur), dari kedua fungsi ini dijelaskan sebagai berikut:

1) Fungsi budgetair (sumbangan keuangan negara) Fungsi regulated (Pengatur)

2) Filsafat Negara

3) Kejelasan Undang-Undang dan peraturan perpajakan

4) Tingkat pendidikan penduduk/ wajib pajak

\section{c. Jenis Pajak}

Menurut (Suntono \& Kartika, 2015)Terdapat berbagai jenis pajak, yang dapat dikelompokkan menjadi tiga, yaitu pengelompokan menurut golongan, menurut sifat, dan menurut lembaga pemungutnya.

1) Menurut Golongan

a) Pajak golongan

b) Pajak tidak langsung

2) Menurut sifat

a) Pajak subyektif

b) Pajak obyektif

3) Menurut lembaga pemungut

a) Pajak Negara (pusat)

b) Pajak Daerah

\section{d. Obyek Pajak Penghasilan}

Menurut (UU No.11 Tahun 2016, 2016)yang termasuk objek pajak penghasilan adalah sebagai berikut:

Pengertian atau imbalan dengan pekerjaan atau jasa yang diterima atau diperoleh termasuk gaji, upah, tunjangan, honorarium, komisi, bonus, gratifikasi, uang pensiun, atau imbalan dalam bentuk lainnya, kecuali ditentukan lain dalam Undang-Undang PPh.

\section{e. Subjek Pajak Penghasilan}

Subjek pajak penghasilan adalah segala sesuatu yang mempunyai potensi untuk memperoleh penghasilan dan menjadi sasaran untuk dikenakan pajak penghasilan. subjek pajak dikelompokkan sebagai berikut:

1) Subjek pajak orang pribadi adalah orang pribadi sebagai subjekpajak dapat bertempat tinggal atau berada di indonesia ataupun di luar Indonesia;

2) Subjek pajak yang belum terbagi sebagai satu kesatuan menggantikan yang berhak

3) Subjek pajak badan

4) Subjek pajak badan Usaha Tetap

f. Sistem Pemungutan Pajak

Pemungutan pajak dikenal beberapa sistem pemungutan yang digunakan sebagai berikut (Waluyo, 2014):

1) Official Assessment System

2) Self Assessment System

3) With Holding System

\section{g. Pengertian Pengusaha Kena Pajak}

Pengusaha adalah Orang Pribadi atau Badan dalam bentuk apapun yang dalam kegiatan usaha atau pekerjaannya menghasilkan Barang KenaPajak (BKP), mengimpor Barang Kena Pajak (BKP), mengekspor Barang Kena Pajak (BKP), melakukan usaha perdagangan, memanfaatkan BarangKena Pajak (BKP) tidak berwujud dari luar daerah pabean, melakukanusaha Jasa Kena Pajak (JKP), atau memanfaatkan Jasa Kena Pajak (JKP)dari luar daerah pabean(www.pajak.go.id, 2013a). 
Fungsi dari dikukuhkannya Pengusaha Kena Pajak (PKP) adalah sebagai berikut:

1) Pengawasan dalam melaksanakan hak dan kewajiban Pengusaha KenaPajak (PKP) di bidang PPN dan PPnBM

2) Sebagai identitas PKP yang bersangkutan dalam melaporkan PPN.

3) Sarana dalam pemenuhan kewajiban pajak Pertambahan Nilai dan Pajak Penjualan Barang Mewah (PPnBM).

\section{h. Hak Wajib Pajak}

Menurut (Rachmawati \& Sariono, 2011)hak-hak Wajib Pajak yang diatur dalam undang- undang perpajakan adalah sebagai berikut:

1) Hak untuk mendapatkan pembinaan dan pengarahan dari fiskus.

2) Hak untuk membetulkan Surat Pemberitahuan (SPT).

3) Hak untuk memperpanjang waktu penyampaian SPT

4) Hak untuk menunda atau mengangsur pembayaran pajak.

5) Hak untuk memperoleh kembali kelebihan pembayaran pajak

6) Hak mengajukan keberatan dan banding.

7) Hak kerahasiaan bagi Wajib Pajak.

8) Hak untuk pengurangan Pajak Bumi dan Bangunan.

9) Hak untuk pembebasan pajak.

10) Hak pengembalian pendahuluan kelebihan pembayaran pajak

11) Hak untuk mendapatkan pajak ditanggung pemerintah

12) Hak untuk mendapatkan insentif pajak.

\section{METODE PENELITIAN}

\subsection{Jenis Penelitian}

Peneliti menggunakan jenis penelitian kualitatif. Menurut Bogdan dan Taylor (L.J. Maelong, 2011:4) Qualitative Research adalah diungkapkan sebagai prosedur penelitian yang menghasilkan data deskriptif berupa kata-kata tertulis atau lisan dari orang-orang dan perilaku yang dapat diamati.

Pada hal ini dalam mengumpulkan, mengungkapkan berbagai masalah dan tujuan yang hendak dicapai maka penelitian ini dilakukan dengan dengan pendekatan interpretatif. Paradigma Interpretatif berasal dari ilmu social dan dicetuskan oleh Burrel dan Morgen pada tahun 1979. Kebangkitannya sebagai filsafat jerman yang menitikberatkan pada peranan Bahasa, interpretasi dan pemahaman dalam ilmu sosial

\subsection{Sumber Data}

Penelitian ini menggunakan data primer dan data sekunder. Data primer diperoleh dari hasil pembagian hasil wawancara. Sementara data sekunder diperoleh dari hasil dokumentasi, pengambilan dokumen pada lokasi penelitian. Informan dalam penelitian ini adalah sebagai berikut:

1) Petugas Pajak bagian penagihan KPP Pratama Makassar Utara;

2) Account Representative (AR) KPP Pratama Makassar Utara;

3) Wajib pajak UMKM di KPP Pratama Makassar Utara.

\subsection{Analisis Data}

Analisis data yang digunakan adalah analsisi data kualitatif menurut Miles dan Hiberman dalam Sugiyono, (2013), mengemukakan bahwa aktivitas dalam analisis data kualitatif dilakukan secara interaktif dan berlangsung secara terus menerus sampai tuntas, sehingga datanya sudah jenuh. Aktivitas dalam analisis data, yaitu data reduction, data display, dan consclusion drawing/verification. 


\section{HASIL DAN PEMBAHASAN}

\subsection{Pokok - Pokok PP No. 23 Tahun 2018}

Terkait dengan PP No. 23 Tahun 2018, maka perlu terlebih dahulu untuk mengetahui garis besar apa saja yang menjadi pokok - pokok aturan dalam PP No. 23 Tahun 2018.

1. Tarif pajak

2. Yang tidak termasuk dalam pengertian wajib pajak dalam PP No. 23 Tahun 2018

3. Wajib pajak memilih untuk dikenai Pajak Penghasilan berdasarkan tarif Pasal 17 ayat (1) huruf a, Pasal 17 ayat (2a), atau Pasal 31E Undang-undang Pajak Penghasilan. Dalam hal ini Wajib Pajak wajib menyampaikan pemberitahuan kepada Direktur Jenderal Pajak;

4. Wajib pajak badan berbentuk persekutuan komanditer atau firma yang dibentuk oleh beberapa Wajib Pajak orang pribadi yang memiliki keahlian khusus menyerahkan jasa sejenis dengan jasa sehubungan dengan pekerjaan bebas sebagaimana dimaksud dalam Pasal 2 ayat (4);

5. Wajib pajak badan memperoleh fasilitas pajak penghasilan berdasarkan:

a. Pasal 13A UU Pajak Penghasilan; atau

b. Peraturan Pemerintah Nomor 94 Tahun 2010 tentang Perhitungan Penghasilan Kena Pajak dan Pelunasan Pajak Penghasilan dalam Tahun Berjalan berserta perubahan atau penggantinya; dan

c. Wajib pajak berbentuk bentuk usaha tetap.

6. Jangka waktu pengenaan tarif
Jangka Waktu Pengenaan Tarif Jangka waktu tertentu pengenaan pajak paling lama:

a. 7 (tujuh) Tahun Pajak bagi Wajib Pajak orang pribadi;

b. 4 (empat) Tahun Pajak bagi Wajib Pajak badan berbentuk koperasi, persekutuan komanditer, atau firma; dan

c. 3 (tiga) Tahun Pajak bagi Wajib Pajak badan berbentuk perseroan terbatas. Jangka waktu sebagaimana dimaksud terhitung sejak:

1) Tahun Pajak Wajib Pajak terdaftar, bagi Wajib Pajak yang terdaftar sejak berlakunya Peraturan Pemerintah ini, atau

2) Tahun Pajak berlakunya Peraturan Pemerintah ini, bagi Wajib Pajak yang telah terdaftar sebelum berlakunya Peraturan Pemerintah ini.

7. Ketentuan khusus dalam PP 23 Tahun 2018 adalah pada saat PP ini mulai berlaku, bagi Wajib Pajak yang sejak awal Tahun Pajak 2018 sampai dengan sebelum Peraturan Pemerintah ini berlaku memenuhi syarat untuk menjalankan kewajiban perpajakan berdasarkan Peraturan Pemerintah Nomor 46 Tahun 2013 tentang Pajak Penghasilan atas Penghasilan dari Usaha yang Diterima atau Diperoleh Wajib Pajak yang Memiliki Peredaran Bruto Tertentu, namun tidak memenuhi ketentuan Wajib Pajak yang dikenai Pajak Penghasilan final berdasarkan Peraturan Pemerintah ini, berlaku ketentuan sebagai berikut:

a. Untuk penghasilan dari usaha sebagaimana dimaksud dalam Pasal 2 ayat (1) yang diterima atau diperoleh sejak awal Tahun Pajak sampai dengan sebelum Peraturan Pemerintah ini berlaku, dikenai 
Pajak Penghasilan dengan tarif $1 \%$ (satu persen) dari peredaran bruto setiap bulan;

b. Untuk penghasilan dari usaha sebagaimana dimaksud dalam Pasal 2 ayat (1) yang diterima atau diperoleh sejak Peraturan Pemerintah ini berlaku sampai dengan akhir Tahun Pajak 2018, dikenai Pajak Penghasilan dengan tarif 0,5\% (nol koma lima persen) dari peredaran bruto setiap bulan; dan

c. Untuk penghasilan dari usaha sebagaimana dimaksud dalam Pasal 2 ayat (1) yang diterima atau diperoleh mulai Tahun Pajak 2019, dikenai Pajak Penghasilan berdasarkan tarif Pasal 17 ayat (1) huruf a, Pasal 17

d. ayat (2a), atau Pasal 31E Undangundang Pajak Penghasilan.

\subsection{Penerapan PP No. 23 Tahun 2018 Pada Wajib Pajak UMKM di Kantor Pelayanan Pajak Pratama Makassar Utara}

Penelitian ini bertujuan untuk mengetahui penerapan PP 23 Tahun 2018 pada Wajib Pajak UMKM di Kantor Pelayanan Pajak Pratama Makassar Utara. Penelitian ini dilakukan dengan melakukan wawancara kepada informan penelitian yang terdiri dari petugas pajak dan wajib pajak UMKM di wilayah kerja KPP Pratama Makassar Utara.

Berdasarkan hasil wawancara diketahui bahwa penerapan PP 23 Tahun 2018 terhadap wajib pajak UMKM di wilayah kerja KPP Pratama Makassar Utara diberlakukan per 1 Juli 2018. Dalam jawabannya Account Representatif mengatakan bahwa:

"Sejak aturan tersebut mulai diberlakukan di Makassar juga sudah mulai memberlakukan yakni per 1 Juli 2018".

"Pemberlakuan PP NO 23 Tahun 2018 sudah dimulai per tanggal 1 july 2018 .hal ini berbanding lurus dengan pemberlakuan PP NO 46 Tahun 2013 sebelumnya yang masih berlaku sejak tanggal dikeluarkannya sampai dengan bulan july 2018".

Dalam kurun dua tahun ini menurut informan kepatuhan wajib pajak cenderung meningkat dan hal tersebut tidak dapat dilepaskan dari adanya regulasi baru PP 23 Tahun 2018 yang diterapkan mulai 1 july 2018. Sejak diberlakukannya respon positif dari wajib pajak terlihat jelas.Hal ini dapat dilihat dengan wajib pajak pada sektor UMKM yang melaporkan dan membayar pajaknya tepat waktu. Tidak hanya itu dengan adanya pelayanan 24 jam dari Account Representatif membukakomunikasi langsung dengan wajib pajak dalam pembayaran pajaknya. Kemudahan yang diberikan kepada wajib pajak melalui aturan ini membuat para pelaku usaha tidak kesulitan menghitung berapa besaran pajak yang akan dibayarkan. Tentu saja aturan ini mendatangkan manfaat melalui ketepatan waktu dan jumlah bayar dikarenakan adanya kemudahan bagi wajib pajak UMKM dalam menunaikan kewajiban perpajakannya.

Berbanding lurus dengan statement pelaku UMKM yang dikenakan PP 23 Tahun 2018. Pemberlakuan aturan baru ini memberikan kemudahan bagi pelaku usaha diakarenakan beban pajak yang ditanggung oleh pelaku usaha lebih kecil dibandingkan beban pajak sebelumnya sehingga pelaku usaha memiliki kemampuan investasi dan 
mengembangkan usahanya.Seperti yang dikatakan Bapak Franki bahwa :

"Pada awalnya penerapan PP NO 46 Tahun 2013 dianggap tidak memenuhi asas keadilan bagi wajib pajak terkhusus pelaku usaha, dilihat dari segi tarifnya pun yaitu $1 \%$. sejak diberlakukannya per tanggal 1 july 2018 PP NO 23 Tahun 2018 dengan tariff pelaku usaha menanggap ini adalah bentuk kebijakan yang dilakukan pemerintah dengan memberikan kemudahaan dan kesederhanaan bagi pelaku usaha dengan membayarkan pajak hanya sebesar 0,5\% dari omzet".

Penurunan tarif kepada wajib pajak UMKM menjadi $0,5 \%$ dari sebelumnya $1 \%$ sangat meringankan mereka. Penurunan tarif sampai setengah dari tarif sebelumnya dengan dasar penghasilan dalam sebulan merupakan kebijakan yang tepat.Kebijkan penurunan tarif pada wajib pajak UMKM ini sesuai dengan prinsip certainty, di mana pajak tidak ditentukan secara sewenangwenang, sebaliknya pajak itu harus dari semula jelas bagi semua Wajib Pajak dan seluruh masyarakat.Penurunan tarif pajak terhadap wajib pajak UMKM menandakan bahwa pemerintah tidak bertindak sewenang - wenang, dan justru sebaliknya membantu pertumbuhan ekonomi.

Pada dasarnya penerapan PP No. 23 Tahun 2018 adalah untuk meringankan beban UMKM karena diberikan penurunan tarif.Kebijakan tersebut dengan mempertimbangkan kondisi UMKM secara umum, agar tidak bias.Hal ini sejalan dengan prinsip pemunguntan pajak yaitu prinsip equality.Prinsip equality menekankan bahwa pajak harus adil dan merata, dikenakan kepada orangorang pribadi sebanding dengan kemampuannya untuk membayar pajak tersebut, dan sesuai dengan manfaat yang diterimanya. Pertimbangan manfaat pajak tentu tidak dirasakan langsung oleh para pelaku usaha UMKM, akan tetapi yang dirasakan langsung manfaatnya adalah tarif pajak jauh lebih rendah.

Menurut keterangan pihak KPP Pratama Makassar Utara, dalam penggolongan wajib pajak UMKM dan prosedurnya mereka mengacu pada PP No. 23 Tahun 2018 dan diperjelas dengan Peraturan Menteri Keuangan No. 99/PMK.03/2018 sebagai peraturan pelaksanaannya. Berdasarkan peraturan Menteri Keuangan diketahui bahwa Pajak Penghasilan yang terutang berdasarkan Peraturan Pemerintah Nomor 23 Tahun 2018 dilunasi dengan cara: (a). disetor sendiri oleh Wajib Pajak yang memiliki peredaran bruto tertentu dilakukan setiap bulan paling lama tanggal 15 (lima belas) bulan berikutnya setelah Masa Pajak berakhir.; atau (b). dipotong atau dipungut oleh Pemotong atau Pemungut Pajak yang ditunjuk sebagai Pemotong atau Pemungut Pajak. Hal ini sejalan dengan prinsip pemungutan pajak yaitu prinsip convenience, di mana wajib pajak UMKM dalam menunaikan kewajiban perpajakannya tidak dalam waktu yang menyulitkan mereka karena diberikan tenggat waktu 15 hari.

Selanjutnya, dalam menunaikan kewajiban perpajakannya, wajib pajak UMKM di wilayah kerja KPP Pratama Makassar Utara tidak dipersulit dengan dalam pengurusan penyetoran di mana wajib pajak UMKM tidak perlu lagi mengurus Surat Keterangan Bebas (SKB) dalam hal bertransaksi dengan bendahara . sesuai dengan penjelasan Account Representatif bahwa :

"Penjelasan pertanyaan yang sudah sangat jelas saat kita membaca isi PP. 
23 dan PMK-99 tahun 2018, bahwa wajib pajak UMKM diberikan penurunan tarif sebelumnya $1 \%$ menjadi 0,5\%. Kemudian wajib pajak UMKM tidak perlu lagi mengurus Surat Keterangan Bebas dalam hal bertransaksi dengan Bendahara cukup mengurus Surat Keterangan Pengguna PP. 23 yang bahkan untuk saat ini sudah bisa bermohon secara online".

Wajib pajak UMKM hanya cukup mengurus Surat Keterangan Pengguna PP. No. 23 Tahun 2018 yang bahkan saat ini sudah dapat diurus secara online. Hal ini sejalan dengan prinsip pemungutan pajak yaitu prinsip economy, di mana biaya pemungutan bagi kantor pajak dan biaya memenuhi kewajiban pajak oleh Wajib Pajak hendaknya sekecil mungkin. Jika pengurusan adminsitrasi perpajakan dilakukan secara online maka biaya yang dikeluarkan wajib pajak UMKM dalam memenuhi kewajiban semakin murah dan tidak menghalagi wajib pajak UMKM dalam melakukan kegiatan usahanya.

\section{PENUTUP}

\subsection{Simpulan}

Berdasarkan hasil penelitian dan pembahasan diketahui bahwa penerapan PP 23 Tahun 2018 pada Wajib Pajak UMKM di Kantor Pelayanan Pajak Pratama Makassar Utara sudah berjalan dengan baik dan sesuai dengan prinsip prinsip pemungutan pajak. Besaran tarif pajak yang diturunkan menjadi 0,5\%, administrasi perpajakan yang murah dan prosedur penyetoran yang mudah merupakan gambaran dari diterimanya PP 23 Tahun 2018 pada sektor UMKM. Hal ini sesuai dengan prinsip pemungutan equality, certainly convenience, dan economy.

\subsection{Saran}

Saran dari penelitian ini adalah kepada pihak Direktorat Jendral Pajak (DJP) agar lebih masif dan terarah dalam melakukan sosialisasi peraturan tersebut. Selain itu, kegiatan sosialisasi yang dilakukan di KPP, DJP lewat masing masing KPP juga dapat mengirimkan penjelasan dengan disertai contohcontoh terkait dengan: (1). Penghitungan Pajak Terutang; (2). Tata Cara Pembayaran/Pelaporan; (3). Surat Keterangan Bebas; (4). Penentuan Jangka Waktu; (5). Wajib Pajak Yang Dikecualikan dari PP 23 Tahun 2018, kepada seluruh Wajib Pajak yang telah terdaftar sebagai Wajib Pajak yang memiliki peredaran bruto tertentu yang terdaftar pada masing-masing KPP. Guna meningkatkan kesadaran masyarakat terkait pentingnya sadar membayar pajak tepat waktu.

\section{DAFTAR PUSTAKA}

Economy.Okezone.Com. (2013). Pajak Umkm, Sederhana Tapi Tidak Adil. Retrieved February 24, 2018, From Https://Economy.Okezone.Com/R $\mathrm{ead} / 2013 / 12 / 16 / 317 / 912925 / \mathrm{Pa}$ jak-Umkm-Sederhana-Tapi-TidakAdil

Rachmawati, A. R., \& Sariono, J. N. (2011). Upaya Hukum Wajib Pajak Atas Surat Ketetapan Pajak Kurang Bayar Yang Ditetapkan Oleh Fiskus Dalam Pemenuhan Hak Wajib Pajak. Perspektif, 16(4), 196-213.

Rakyatku.com. 2018. Hingga Maret, Baru 28,40 Persen Wajib Pajak Makassar yang Melapor. https://rakyatku.com/read/93360 /hingga-maret-baru-28-40-persenwajib-pajak-makassar-yangmelapor.

Suntono, \& Kartika, A. (2015). Pengaruh Pemahaman Peraturan Pajak Dan 
Pelayanan Aparat Pajak Terhadap Kepatuhan Wajib Pajak Dengan Preferensi Risiko Sebagai Variabel Moderasi (Studi Kasus Pada Umkm Yang Terdaftar Di Kpp Pratama Demak). Dinamika Akuntansi, Keuangan Dan Perbankan, 4(1), 29-38.

Https://Doi.Org/10.1017/Cbo978 $\underline{1107415324.004}$

Uu No.11 Tahun 2016. (2016). UndangUndang Republik Indonesia No.11 Tahun 2016. Retrieved From Http://Ketentuan.

Pajak.Go.Id/Index.Php?R=Aturan/ Rinci\&Idcrypt=0jqgpke\%3d

Waluyo. (2014). Perpajakan Indonesia. In Perpajakan Indonesia Edisi 11 Buku 1 (P. 496).

Www.Pajak.Go.Id. (2013a). Pengukuhan Pengusaha Kena Pajak | Direktorat Jenderal Pajak. Retrieved February 24, 2018, From Http://Www.Pajak.Go.Id/Content/ 2-Pengukuhan-Pengusaha-KenaPajak

Www.Minghadi.Com. (2013). Pro Kontra (Peraturan Pemerintah) PP 23 Tahun 2018 | Sharing Ideas. Retrieved February 24, 2018, From Http://Www.Minghadi.Com/ProKontra-Peraturan-Pemerintah-Pp46-Tahun-2013/

Yenni Mangoting. (2000). Menyongsong Tax Reform 2001: Khusus Pajak Penghasilan. Jurnal Akuntansi Dan Keuangan, 2(2), 116-126. Retrieved From Http://Puslit2.Petra.Ac.Id/Ejourna l/Index.Php/Aku/Article/View/15 $\underline{672}$

erryanto, M., \& Toly, A. A. (2013). Pengaruh Kesadaran Wajib Pajak, Kegiatan Sosialisasi Perpajakan, Dan Pemeriksaan Pajak Terhadap Penerimaan Pajak Penghasilan Di Kpp Pratama Surabaya Sawahan. Tax And Accounting Review, 1(1), 125-133. 